\title{
A percepção visual do ambiente como influência na experiência do cliente
}

\author{
Rebeca Gomes Batista Rodrigues"; \\ Márcio Carneiro dos Santos;
}

resumo:

A oferta de modelos comerciais se expande não se restringindo a comercialização de bens e serviços, mas de experiência de compra e uso estratégico de estímulos multissensoriais impactantes na esfera emocional dos compradores. Norman (2008) explana que alguns objetos podem evocar emoções nos usuários e essas respostas podem provocar consequências positivas em todo o período de uso. Além disso, autores como Desmet (2013) dizem que essas emoções positivas são essenciais para o fator de compra, criando uma relação direta entre emoções e objetos. Com o processo de consumo cada vez mais latente, o próprio ambiente comercial ganha espaço no processo de construção emocional. Kotler (1974) e Mehrabian e Russel (1974) avaliaram como a atmosfera do ponto de venda também influenciava nas emoções humanas e, consequentemente, determinavam o fator de compra dos produtos pela experiência agradável. Essa experiência do cliente é feita a partir de aspectos objetivos e subjetivos, os designers não podem moldar uma experiência individual, mas a partir de um contexto projetado as pessoas irão interagir e sentir suas próprias vivências. (FREIRE,2009). Moreira (2019) reflete que a visão é o primeiro contato entre pessoas e produtos, tendo maior impacto na percepção estética que pode gerar emoções nos consumidores e, apesar de não ser o único, é o sentido responsável pelo maior recebimento de informações retidas pelo ser humano. Nesta perspectiva, esta pesquisa tem como objetivo a identificação dos elementos visuais utilizados nos supermercados gourmet na cidade de São Luís e como a percepção destes elementos no ambiente influencia a experiência de compra dos usuários. O estudo se configura como uma pesquisa de cunho exploratório e abordagem qualitativa. Com seus procedimentos de coleta e análise ainda sendo configurados, o estudo de caso poderá contar com entrevistas com os consumidores do local, a análise comparativa dos ambientes através de imagens fotográficas e com entrevistas semiestruturadas com os comerciantes e designers envolvidos nos projetos. A pesquisa se propõe a avaliar a experiência estética com a reação automática, ou visceral (NORMAN, 2008) de interação dos consumidores com os elementos presentes no estabelecimento. Como direcionamento para análise dos elementos visuais identificados, propõem-se as metodologias desenvolvidas por Sanzi (2006) e Feijó e Botelho (2012), cujos principais objetos de análise são: layout dos setores das lojas, sinalização, localização das linhas de produtos, apresentação dos produtos, combinação de cores, colocação de etiquetas promocionais e de preços, utilização de equipamentos expositores, materiais promocionais como displays, quadros e cartazes e acabamento dos materiais arquitetônicos utilizados pela loja. Entender o comportamento do consumidor se faz necessário frente à importância do setor varejista. Imbuzeiro e Filho (2016) explanam que o estudo do comportamento do cliente, como forma de aumentar a performance de vendas de um estabelecimento, sem levar em conta seu sentido emocional e como a relação com o ambiente interfere no seu comportamento, é negligenciar as reais motivações do consumidor. Ao conhecer os fatores que interferem no ato de compra, é possível desenvolver estratégias que possam ser úteis para o desenvolvimento mercantil do empreendimento, assim também para a satisfação do consumidor. Como resultado esperado, a pesquisa busca avaliar se o projeto de design estratégico na

\footnotetext{
1 http://lattes.cnpq.br/1932394033484966

2 http://lattes.cnpq.br/8231237935065420
} 
construção desses elementos visuais acima elencados é relevante para a experiência dos clientes e como eles podem impactar nas emoções dos usuários.

palavras-chave:

Percepção visual; Design emocional; Experiência do usuário; Atmosfera do ambiente

\section{REFERÊNCIAS}

DESMET, P. M. A. Designing Emotions. 2002. Delft University of Technology, 2002.

FEIJO, Fabrício Rodrigues; BOTELHO, Delane. Efeito dos fatores de merchandising nas vendas v.4, n.3

FREIRE, K. M. Reflexões sobre o conceito de design de experiências. Strategic Design Research Journal, v. 2, p. 37-44, 2009.

GATTO del, Stefania. L'atmosfera del punto vendita quale strumento di differenziazione dell'insegna: una verifica empírica delgli effetti della variabile olfativa. Congresso Internazionale "Le tendenze Del Marketing" Venezia, 2002.

IMBUZEIRO, P. E. de A., \& SILVA, J. L. da. A Experiência do Consumo e a Lealdade do Cliente: Uma Análise dos Atributos Definidores da Compra em Supermercados. Interfaces Científicas Humanas E Sociais, v. 4 n. 3, 141-158.

KOTLER, P. Atmospherics as a Marketing Tool. Journal of Retailing, v. 49 (Winter), 48-64, 1973.

NORMAN, D. A. Design Emocional: por que adoramos (ou detestamos) os objetos do dia-adia. Tradução d ed. Rio de Janeiro: Rocco, 2008.

MOREIRA, Andréa de Castro. Experiência estética no design: relações entre percepção visual e emoção. Dissertação de Mestrado. Universidade Federal do Rio Grande do Sul. Rio Grande do Sul,2019.

PINE, J.; GILMORE, J. H. 1998. Welcome to the experience economy. Harvard Business Review, 76:97-105.

SANZI, Gianpietro. A influência dos fatores visuais de design na percepção de valor de compra no varejo de auto-serviço. Dissertação (Mestrado em Administração e Negócios). Faculdade de Administração, Contabilidade e Economia. Pontifícia Universidade Católica do Rio Grande do Sul. Rio Grande do Sul, p. 163. 2006. 